\title{
Anna M. Kola, Piotr Kostyło, Hanna Solarczyk-Szwec (red.), Wychowanie jednostki i wspólnoty do wartościowego życia, t. 1, ss. 292; Anna Jakubowicz-Bryx, Jolanta Nowak, Hanna Solarczyk-Szwec (red.), Wychowanie jednostki i wspólnoty do wartościowego życia, t. 2, Wydawnictwo Naukowe UMK, Toruń 2016, ss. 236
}

Mierzenie się z pytaniem o wartości jest trudne, a odpowiedź na nie staje się jeszcze bardziej skomplikowana, gdy pytamy o wychowanie do wartości. Przechodzimy bowiem w tym momencie od porządku normatywnego do porządku praktycznego, w którym umiejętność poruszania się określana była cnotą roztropności, czyli mądrości praktycznej (Dziaczkowska 2013), a roztropności człowiek uczy się całe życie. Mimo tych trudności namysł nad wartościami w pedagogice jest nieodzowny. To one wyznaczają przecież teleologię wychowania - wyznaczają nawet wówczas, gdy nie wyraża się ich wprost, deklarując aksjologiczną neutralność. Podkreśla to szczególnie mocno Jacques Maritain, który rozpoczynając swoje pedagogiczne studium Education at the Crossroadas, identyfikuje nieporozumienia w wychowaniu, a za pierwsze uznaje zignorowanie celów (1943, s. 2). Doskonałość metod i środków wychowawczych nie zastąpi zatem mądrości wskazującej na wartości jako na cele wychowania.

W 2015 roku dwa środowiska Polskiego Towarzystwa Pedagogicznego - bydgoskie i toruńskie, w ramach przygotowań do zaplanowanego na 2016 rok Zjazdu Pedagogicznego, którego tematyka poświęcona została wartościom, zorganizowały konferencję pod hasłem: „Wychowanie jednostki i wspólnoty do życia wartościowego". Interesujące dyskusje, jakie toczyły się przez dwa dni najpierw w Bydgoszczy, a następnie w Toruniu przyniosły efekt w postaci dwutomowej publikacji, zatytułowanej tak samo, jak konferencyjne obrady. Zamieszczono w niej w sumie 27 artykułów poświęconych zarówno samym wartościom, jak i próbom ich realizacji w praktyce edukacyjnej. Nie jest to z pewnością opracowanie podręcznikowe, zaplanowane 
i konsekwentnie przeprowadzone. Jego lektura przynosi jednak wiele interesujących stwierdzeń, wobec których trudno przejść obojętnie. Niekiedy skłaniają one do refleksji, a niekiedy prowadzą do wewnętrznej z nimi dyskusji. Zanim spróbuję wprowadzić w dyskusję, którą wywołały w moim przypadku, chciałbym zwrócić uwagę na dwa aspekty przygotowanej w Wydawnictwie Naukowym UMK publikacji. Pokazuje ona, po pierwsze, kontekst edukacji moralnej, jaki wytworzył się na początku XXI wieku i który stał się punktem odniesienia dla dyskusji pedagogicznych. Po drugie, wskazuje na teoretyczne sposoby rozwiązywania zidentyfikowanych problemów, które - być może staną się podstawą krytycznej oceny przez kolejne pokolenia pedagogów.

Pierwszym problemem, na który zwrócono uwagę, jest powiązanie w Polsce wychowania do życia wartościowego z edukacją religijną. Temat ten dochodzi do głosu w zasadniczej części tekstów, poświęconych systemom aksjonormatywnym w wychowaniu (część I tomu 1). W polskiej edukacji wytworzyła się specyficzna sytuacja w zakresie wychowania moralnego, wychowania „do życia wartościowego”. Po przywróceniu nauczania religii w szkołach publicznych potraktowano je jako przestrzeń wychowania moralnego, co znalazło wyraz w podejściu do etyki jako przedmiotu alternatywnego wobec religii, przeznaczonego dla uczniów niedeklarujących chęci uczestnictwa w lekcjach religii. Założono zatem, że wychowanie moralne realizowane będzie na lekcjach etyki albo na lekcjach religii. Normy moralne, wypracowywane w ramach tych dwóch dyscyplin, nie muszą pozostawać w konflikcie. Zwolennik etyki praw człowieka będzie dochodził do rozstrzygnięć bliskich etyce religijnej, a zwłaszcza chrześcijańskiej (rozbieżności wystąpią, jeżeli kluczem do rozwiązywania dylematów moralnych uczynimy np. utylitaryzm). Zasadnicza różnica dotyczy jednak motywacji do przestrzegania określonych norm. Religia odwołuje się w tym względzie do autorytetu Boga i konieczności przestrzegania norm ze względu na relację z Nim. W etyce niezależnej punktem odniesienia dla moralności staje się godność człowieka lub realizacja określonego modelu życia społecznego. Charakter argumentów uzasadniających moralność staje się znaczący, jeżeli zaczniemy je rozważać w perspektywie przemian społeczno-kulturowych ostatniego ćwierćwiecza, a konkretniej przemian religijnych, polegających na osłabianiu wpływu religii. Znaczący procent uczniów, uczęszczających na lekcje religii, należałoby uznać za agnostyków, co oznacza, że nieuzasadnione jest motywowanie ich do „życia wartościowego” relacją z Bogiem. Zwieńczeniem edukacji religijnej u tej grupy uczniów jest przekonanie, że normy moralne są powiązane $\mathrm{z}$ religią, a umieszczenie tego stwierdzenia w kontekście wątpliwości odnośnie do istnienia Boga i nietraktowania Go jako punktu odniesienia we włas- 
nym życiu prowadzi do odrzucenia moralności. Alternatywą staje się wówczas pewna postać „etyki autentyczności”, o której pisze Danuta Wajsprych (t. 1, s. 37-49), polegającej na uzgadnianiu działania nie z rozumem rozpoznającym dobro, ale z uczuciami (znanej w historii etyki jako sentymentalizm) - niestety, postać zdegenerowana, sprowadzająca się do egoizmu, gdyż uczucia - ze względu na ich subiektywny charakter - kierują przede wszystkim ku podmiotowi i niejednokrotnie pozostają ślepe na dobro obiektywne (czyli dobro przedmiotu odniesienia).

W prezentowanym zbiorze znajdujemy dwa artykuły nawiązujące wyraźnie do nakreślonego powyżej problemu. Piotr Kostyło podejmuje go w artykule pod tytułem: Religia, etyka i edukacja. O źródłach życia wartościowego (t. 1, s. 19-35), odwołując się do prac pedagogicznych Émile’a Durkheima. Warto prześledzić ten tekst z dwóch względów. Po pierwsze, z uwagi na rekonstrukcję myśli francuskiego filozofa, która pokazuje, że moralność zawsze wymaga jakiegoś punktu odniesienia, a Durkheim uczynił nim społeczeństwo (zastępując w ten sposób religię tradycyjną religią społeczeństwa). Po drugie, ze względu na wysuwaną propozycję odnośnie do zmian w szkolnym programie nauczania. Sugeruje objęcie lekcjami etyki wszystkich uczniów (co niewątpliwie podniosłoby poziom refleksji nad kwestiami etycznymi i uchroniłoby przed subiektywizmem sentymentalizmu moralnego), a przy tym zachowanie lekcji religii (na których zależy przynajmniej części rodziców i uczniów, a do których mają prawo, jeżeli respektowana jest zasada subsydiarności, według której szkoła jedynie wspiera rodziców w wychowaniu, a nie zawłaszcza ich prawa). Drugi artykuł podejmujący wskazany problem został przygotowany przez Małgorzatę Obrycką. W tekście pod tytułem Miejsce etyki niezależnej w procesie kształtowania religijnej tożsamości (t. 1, s. 51-68) autorka odwołuje się do etyki niezależnej Tadeusza Kotarbińskiego. Wypracowana przez polskiego filozofa teoria etyczna jawi się jako wartościowa propozycja, mogąca stanowić fundament dla programu nauczania etyki, tym bardziej że jej treściowa zawartość byłaby akceptowalna dla rodziców o różnych światopoglądach. Małgorzata Obrycka wykorzystuje jednak etykę niezależną Kotarbińskiego jako punkt wyjścia do rozważań na temat programu nauczania... religii. W swojej wypowiedzi wyraża pogląd, według którego szkoła powinna być bezreligijna, a nauczanie religii powinno zostać zastąpione religioznawstwem (to ostatnie stanowisko przypisuje Bogusławowi Milerskiemu zupełnie bezzasadnie - ze stwierdzenia, że pedagogika religii może być uprawiana jako dyscyplina pedagogiczna, a nie tylko teologiczna, wynika, że edukacja religijna może być analizowana w perspektywie humanistycznej w celu zbadania, jak edukacja religijna przyczynia się 
do rozumienia doświadczeń egzystencjalnych i rozwoju humanistycznego, ale nie wynika, że edukacja religijna powinna zostać zastąpiona religioznawstwem; Milerski 1998; 2011). Refleksja nad filozofią Kotarbińskiego prowadzi zatem do wniosków, które nie są uzasadnione merytorycznie i których realizacja naruszyłaby de facto jedną z podstawowych zasad współczesnego państwa, jaką jest zasada subsydiarności.

Drugi wątek, na który warto zwrócić uwagę, dotyczy struktury rozwoju prowadzącego do życia wartościowego. $Z$ zebranych w obydwu tomach tekstów odczytać można swoistą strukturę rozwoju moralnego. Aby ją uwypuklić, odwołajmy się do socjologicznej teorii, autorstwa Margaret Archer. Twierdzi ona, że rozwój jednostki uwarunkowany jest z jednej strony strukturą i kulturą, w jakich przebiega, ale ich wpływ nie jest determinujący. Korzystając ze struktur i z kultury, jednostka formułuje swoje troski w trzech porządkach: naturalnym, praktycznym i społecznym, oraz próbuje na nie odpowiadać. $\mathrm{W}$ owych odpowiedziach korzysta z tego, co otrzymuje od otoczenia, ale nie podchodzi do otrzymanych danych bezkrytycznie - w ich percepcji jest refleksyjna, konfrontując podsuwane rozwiązana z rzeczywistością (Archer 2013). Wpływ uwarunkowań społeczno-kulturowych na rozwój jednostek doskonale widać na przykładzie Brazylii, w której wytwarzane przez wieki struktury społeczne - z podstawowym dla nich rysem kolonializmu - znajdywały oddźwięk w rozwoju jednostek. Zależność tę relacjonuje Hanna Kostyło, odwołując się w jej interpretacji do twórczości Paula Freirego (t. 1, s. 83-105). Z drugiej jednak strony przemiany owych struktur oraz lokalnej kultury są świadectwem ich niedeterminującego wpływu. O owym wpływie pisze również Joanna Madalińska-Michalak, przywołując twórczość Alasdaira MacIntyre'a (t. 2, s. 11-29). Jego analizy odnoszą się do stanu kultury europejskiej, kształtowanej głównie przez indywidualizm, który MacIntyre poddaje krytyce. Autorka artykułu rekonstruuje poglądy MacIntyre’a, aby następnie postawić pytanie o prawomocność wysuwanych przez niego wniosków. Trudno nie przyznać racji owej krytyce. Przyglądając się jednak pracom, które zamieszczono w omawianych tomach, można zauważyć, że indywidualizm kształtuje współczesne myślenie. Wprawdzie tytuł obydwu tomów wspomina o jednostkach i wspólnotach, mówiąc o ich wychowaniu: „Wychowanie jednostki i wspólnoty do...”, jednak żaden z autorów nie zdecydował się na sformułowanie wyraźnych wniosków odnośnie do wychowania wspólnoty. Przyzwyczailiśmy się zatem do patrzenia na wspólnotę przez pryzmat jednostek i do mówienia o wychowaniu... jednostek do wartościowego życia indywidualnego i wspólnotowego. Niestety rolę „wychowania” 
wspólnoty przejmują w tej sytuacji, jak przekonuje Kazimierz Czerwiński, ruchy populistyczne (t. 2, s. 31-61).

Do refleksji nad współczesnym kontekstem socjalizacyjnym skłania także grupa tekstów poświęconych dojrzewaniu do życia w rodzinie. Otwiera ją artykuł Joanny Ostrouch-Kamińskiej na temat partnerstwa w relacji małżeńskiej (t. 1, s. 125-140). Zaliczyć do niej należy ponadto wypowiedzi Alicji Kozubskiej na temat odkrywania roli rodzica (t. 1, s. 163-178) oraz Moniki Błędowskiej, poświęconą doświadczeniom rodzicielskim par żyjących w kohabitacji (t. 1, s. 203-219). Nie bez przyczyny stwierdzam, że przedmiotem tej refleksji nie jest rodzina, ale kontekst, w jakim próbuje się odnaleźć. Aby to wyjaśnić, należy jednak wrócić do pewnych rozróżnień, założonych w ostatnim z przywołanych tekstów. Tradycyjne przeciwstawienie małżeństwa i pary żyjącej w kohabitacji odnosi się do formalnego aspektu związku. Gdybyśmy jednak spróbowali określić wewnętrzną jego strukturę, podziały mogłyby być zupełnie inne. Można by np. podzielić pary na te, których strony kochają siebie nawzajem i biorą za siebie odpowiedzialność, oraz te, które wchodzą w specyficzny układ, polegający na obopólnym czerpaniu korzyści ze wspólnej egzystencji (mogą to być małżeństwo lub związek realizowane na podstawie modelu wspólnoty konstruktywistycznej - czasowej, z przyzwoleniem na szybkie rozwiązanie, gdy wyczerpuje się jej formuła). Nietrudno zauważyć, że granice podziałów nie będą się pokrywały. Możemy bowiem mieć do czynienia zarówno $\mathrm{z}$ formalnymi małżeństwami, w których współmałżonkowie nie biorą za siebie odpowiedzialności, jak również z parami żyjącymi w kohabitacji, które de facto spełniają kryteria małżeństwa - z różnych względów: ekonomicznych, ideologicznych czy społecznych, nieusankcjonowanego. Fakt pozostawania w związku nieformalnym, mimo spełniania przez dwoje ludzi podstawowych wewnętrznych kryteriów małżeństwa i rodziny (troski o siebie nawzajem i troski o wspólne potomstwo), świadczy nie tyle o wyczerpywaniu się formuły małżeństwa i rodziny, ile o poszukiwaniu dla niej nowego kulturowego wyrazu. Czynników owej zmiany jest wiele, poczynając od tego, o którym wspomina Joanna Ostrouch-Kamińska, czyli partnerstwa współmałżonków, które w tradycyjnym modelu rodziny ustępowało miejsca autorytetowi mężczyzny, zabezpieczającego swoich najbliższych od strony ekonomicznej.

Interesujące badania zostały zaprezentowane przez Violettę Kopińską i Hannę Solarczyk-Szwec (t. 2, s. 63-90). Autorki postanowiły przyjrzeć się podstawie programowej kształcenia ogólnego pod kątem występowania w niej lub braku celów nakierowanych na życie wspólnotowe, czyli wpisania we wspomniany dokument nabywania przez uczniów kompetencji społecz- 
nych i obywatelskich. Prezentacja jest ważna, ponieważ pokazuje model badania materiałów źródłowych, a równocześnie przynosi interesujące wyniki. Jak się okazuje, wychowanie do wspólnoty nie stanowi spójnego, uporządkowanego projektu w ramach podstawy programowej kształcenia ogólnego, trudno zatem o ukształtowanie u uczniów postaw prospołecznych i obywatelskich, jeżeli to on staje się wyznacznikiem działalności edukacyjnej. Przy okazji tego artykułu warto jednak zastanowić się także nad ideami, które uformowały myślenie pedagogiczne i podjąć z nimi dyskusję. Od VI Zjazdu Pedagogicznego, który odbył się w Lublinie w 2007 roku, wraca w pedagogice pytanie o pożądany model wspólnoty - czy ma być to wspólnota organiczna, czy konstruktywistyczna (Szahaj 2007). Te dwa modele wspólnotowości przeciwstawiono sobie, a owo przeciwstawienie stało się paradygmatem w myśli pedagogicznej. Deprecjonowana jest przy tym wspólnota organiczna jako bezrefleksyjna i wykluczająca. Wypracowane na terenie filozofii politycznej kategorie odnoszone są jednak, niestety, do podstawowej wspólnoty, w jakiej żyje człowiek, czyli do rodziny. Ona przecież nie powstaje na drodze refleksji, tylko opiera się na naturalnych podstawach, ona również funkcjonuje w określonych granicach i wyraźnie zaznacza, kto jest, a kto nie jest jej członkiem, ona również w pewnym sensie nie pozostawia wyboru (matki, ojca, dziecka nie zmieni się zgodnie z założeniami modelu konstruktywistycznego, nawet gdy życie we wspólnocie z nimi będzie trudne). Jak wychowywać zatem do budowania wspólnoty organicznej, do troski o tę wspólnotę? Jak wychowywać do tego, by mierzyć się z trudnościami, a nie uciekać od nich? Czy wizja wspólnoty konstruktywistycznej, która de facto jest modelem wspólnotowości budowanym w ramach indywidualizmu, nie krępuje pedagogicznego myślenia o wspólnocie? Czy wiara w to, że wspólnotowość konstruktywistyczna pozwoli unikać problemów życia wspólnotowego, nie stanowi przejawu myślenia utopijnego? Do tych pytań należy moim zdaniem - wrócić w refleksji pedagogicznej.

Kolejna grupa artykułów, na którą warto zwrócić uwagę, dotyczy konkretnych wartości realizowanych w pracy pedagogicznej. Należy do nich np. tekst Anny Marii Koli, poświęcony wartościom w pomocy społecznej (t. 2, s. 91-108). Po prezentacji etycznych założeń poszczególnych modeli pomocy społecznej autorka kieruje uwagę czytelnika na niedostrzeganą zazwyczaj wartość prywatności. Cenne jest zwrócenie na nią uwagi ze względu na fakt, że kierowane do poszczególnych jednostek i rodzin formy pomocy zdają się coraz bardziej ją naruszać. Przypisanie do poszczególnych rodzin kilku pracowników o różnych kompetencjach: pracownik socjalny, asystent rodziny, kurator przy dużej rotacji pracowników, z jaką mamy w praktyce do czynie- 
nia, prowadzi niejednokrotnie do wprowadzenia dużej grupy obcych osób w intymne sprawy danej rodziny. Innym tekstem, poświęconym konkretnej wartości, jest artykuł Zygmunta Wiatrowskiego, który podejmuje problem wychowania przez pracę i do pracy (t. 1, s. 69-81). Owo "przez” wyraża w pewnym sensie zarzut, kierowany w stronę współczesnej edukacji, która zapoznała wychowawczą wartość pracy, stanowiącej punkt zetknięcia jednostki z rzeczywistością społeczną - troska o jak najlepsze przygotowanie teoretyczne oraz w zakresie umiejętności i kompetencji nie jest połączona z dążeniem do odkrycia przez dojrzewającego człowieka humanistycznej wartości pracy, z jaką można zetknąć się jedynie w ramach pracy.

Nie sposób w ramach tak krótkiego tekstu podjąć wszystkie wątki, poruszone w obydwu książkach. Są to dobre prace, ponieważ skłaniają do namysłu, czasami sprzeciwu wobec wysuwanych tez, ale z pewnością nie pozwalają zachować obojętności wobec zasygnalizowanych problemów. Zaznaczmy zatem tylko, że czytelnik znajdzie w nich poza wspomnianymi także naukową refleksję Zbigniewa Kwiecińskiego (wprowadzenie w problematykę konferencji), Renaty Sigvy, Wandy Dróżki, Dariusza Sarzały, Renaty Raszki, Ewy Musiał, Przemysława Ziółkowskiego, Marzenny Nowickiej, Jolanty Nowak, Renaty Góralskiej, Anny Jakubowicz-Bryx, Anny Sladek, Aldony Małyski, Małgorzaty Dankowskiej-Kosman oraz Danuty Wiśniewskiej. Jako Postscriptum zamieszczono artykuł Piotra Petrykowskiego na temat „pamięci początku” jako źródła tożsamości i fundamentu dla przyszłości (t. 1, s. 275-292). Jego autor podejmuje poważne wyzwanie wyprowadzenia wniosków pedagogicznych na drodze hermeneutyki egzystencjalnego doświadczenia. Punktem odniesienia dla niej są z jednej strony teksty biblijne jako teksty mądrościowe, a z drugiej literatura filozoficzna. Warto przyjrzeć się i tej pracy, szczególnie w czasach, gdy pedagogika w swej metodologii kładzie akcent na pomiar charakterystyczny dla nauk społecznych, a nawet przyrodniczych, tracąc zdolność refleksji typowo humanistycznej.

Jarosław Horowski

\section{Bibliografia}

Archer M.S. (2013), Człowieczeństwo. Problem sprawstwa, Kraków.

Dziaczkowska L. (2013), Roztropność jako zapoznana sprawność moralna wychowawców, w: I. Jazukiewicz, E. Rojewska (red.), Roztropność i cierpliwość jako sprawności moralne w wychowaniu, Szczecin.

Maritain J. (1943), Education at the Crossroads, New Heven-London. 
Milerski B. (1998), Współczesne koncepcje pedagogiki religijnej, w: tenże (red.), Elementy pedagogiki religijnej, Warszawa.

Milerski B. (2011), Hermeneutyka pedagogiczna. Perspektywy pedagogiki religii, Warszawa.

Szahaj A. (2007), Samotność i wspólnota, w: J. Rutkowiak, D. Kubinowski, M. Nowak, Edukacja - moralność - sfera publiczna, Lublin. 